\title{
Baffling Cause of Upper Gastrointestinal Bleeding!
}

\author{
Amit Soni Nirmaljeet Singh Malhi \\ Department of Gastroenterology and Liver Disease, SPS Hospital, Ludhiana, India
}

\section{Keywords}

Gastrointestinal bleeding · Isolated gastric varices .

Nonvariceal bleeding

\section{Causa desconcertante de hemorragia digestiva alta!}

\section{Palavras Chaves}

Hemorragia digestiva - Varizes gástricas isoladas .

Hemorragia não varicosa

A 53-year-old man presented to the emergency department with recurrent bouts of hematemesis for 2 days. This was associated with dizziness and passage of black tarry stools for 1 day. He did not report any past history of a similar complaint. He denied any recent intake of NSAIDs or chronic alcohol abuse. He was living a healthy life with no comorbidity.

On examination, he had tachycardia and pallor. His systolic blood pressure was $100 \mathrm{~mm} \mathrm{Hg}$ and there was evidence of postural hypotension. There was no sign suggestive of liver disease (spider angioma, decreased body

\section{KARGER}

E-Mail karger@karger.com www.karger.com/pjg (c) 2018 Sociedade Portuguesa de Gastrenterologia
Published by S. Karger AG, Basel Karger
Open access

This article is licensed under the Creative Commons AttributionNonCommercial-NoDerivatives 4.0 International License (CC BYNC-ND) (http://www.karger.com/Services/OpenAccessLicense). Usage and distribution for commercial purposes as well as any distribution of modified material requires written permission. hairs, etc.). Per abdomen examination was unremarkable. His initial blood tests were as follows: hemoglobin $6 \mathrm{~g} / \mathrm{dL}$; white blood cell count $7.4 \times 10^{9} / \mathrm{L}$; platelets $344 \times 10^{9} / \mathrm{L}$; total bilirubin $21.3 \mu \mathrm{mol} / \mathrm{L}$; SGOT $33 \mathrm{IU} / \mathrm{L} ; \mathrm{SGPT} 27$ IU/L; serum albumin $40 \mathrm{~g} / \mathrm{L}$; and INR 1.0 .

The patient was transfused 3 units of packed red blood cells. After hemodynamic stabilization, an upper gastrointestinal (GI) endoscopy was done. Upper GI endoscopy revealed active spurting of blood from a vascular lesion in the gastric fundus. Endoscopically, it appeared as isolated gastric varices, so glue was injected (Fig. 1). His bleeding was controlled with glue injection.

The patient was further evaluated to look for the cause of gastric varices. Color Doppler of the portal venous system was unremarkable. Computed tomographic angiography of the abdomen revealed an arterial plexus crowded in the gastric fundus (arrow in Fig. 2). It was seen to be supplied by the left inferior phrenic artery and a distal splenic artery branch (Fig. 3). The bleeding lesion which mimicked isolated gastric varices on endoscopy was actually an abnormal arterial plexus in the gastric fundus, most probably a congenital abnormality. Glue was used to plug the bleeding punctum but in view of an arterial lesion (pressure is more than a venous lesion) and a large

Dr. Nirmaljeet Singh Malhi

Department of Gastroenterology and Liver Disease SPS Hospital

Ludhiana, 141003 (India)

E-Mail drnjsmalhi@gmail.com 


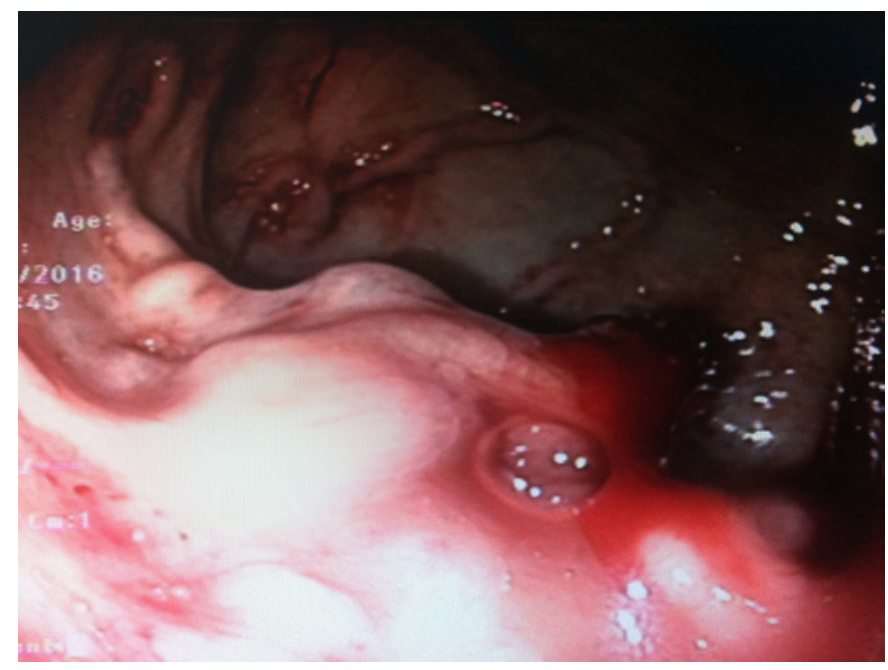

Fig. 1. Endoscopic appearance of the bleeding gastric lesion, mimicking gastric varices.

area protruding into the stomach, chances of repeat massive bleeding were anticipated. He was referred to the interventional radiology department where embolization of the arterial plexus was done.

This case presents a rare cause of GI bleeding; i.e., an abnormal arterial plexus in the gastric fundus, likely of congenital origin. Even a Dieulafoy-like lesion could be a rare form of presentation of such a plexus. Computed tomographic angiography of the abdomen clinched the diagnosis. The lesion which appeared as gastric varix was confirmed to be an abnormal arterial plexus formed by a branch of the left inferior phrenic artery and splenic artery. Embolization of the arterial plexus remains the mainstay of treatment as this therapeutic option eradicates the plexus and hence the chances of recurrence in future. The dissociation between endoscopic and computed tomographic findings makes this case interesting and challenging.

The differential diagnosis in such cases includes isolated gastric varices, atypical Dieulafoy-like lesion, abnormal vessel coursing through the gastric wall (e.g., accessory splenic artery), and rupture of splenic artery aneurysm into the stomach [1-3]. The causes of upper GI bleeding are classified into variceal and nonvariceal causes. The need for differentiation between the two needs to be emphasized as the management varies.

Kervancioglu et al. [2] described a similar presentation of massive GI bleeding where the accessory splenic artery was the culprit and it mimicked isolated gastric varices. Authors managed the patient with coil embolization of

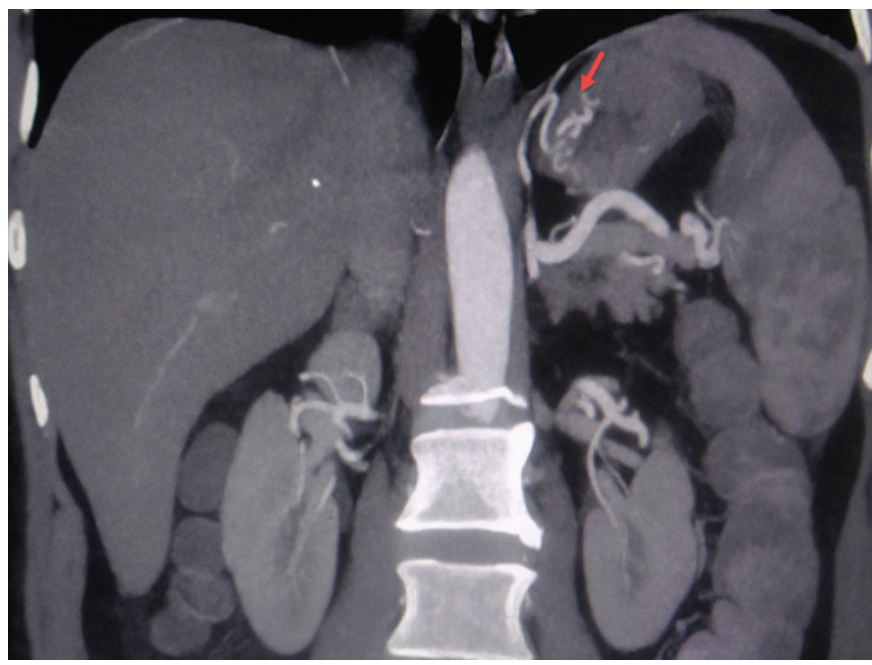

Fig. 2. CT angiography (abdomen): an arterial plexus crowded in the gastric fundus.

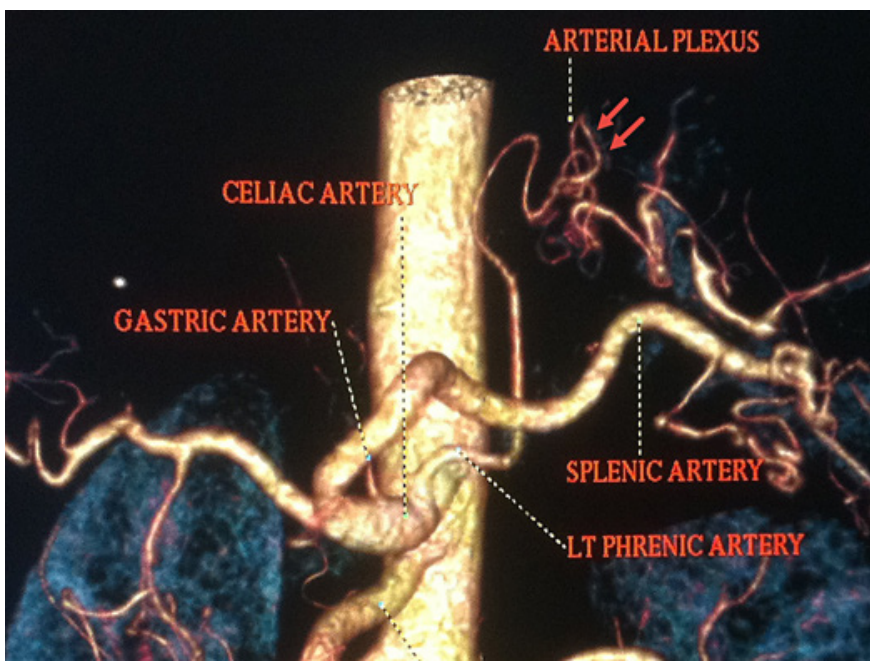

Fig. 3. CT angiography (abdomen): the plexus is supplied by the left inferior phrenic artery and a distal splenic arterial branch.

the artery. Pinto-Marques et al. [3] described a rare case of splenic artery aneurysm which eroded into the gastric wall and presented with massive upper GI bleeding. Here we report the first case of upper GI bleeding due to an abnormal arterial plexus in the gastric wall.

\section{Disclosure Statement}

The authors have no conflicts of interest to declare. 
References
1 Pohle T, Helleberg M, Menzel J, et al: An extraordinary Dieulafoy's lesion presenting as varices of the gastric fundus. Gastrointest Endosc 2001;54:776-779.

2 Kervancioglu S, Yilmaz FG, Gulsen M, Kervancioglu P, Kervancioglu R: Massive upper gastrointestinal bleeding from an accessory splenic artery mimicking isolated gastric var- ices. Folia Morphol (Warsz) 2013;72:366370.

3 Pinto-Marques P, Gíria J, Brito M, Camacho R, Loureiro R: Unusual cause for upper GI bleeding: a splenic artery aneurysm mimicking a Dieulafoy lesion. Role for systematic EUS assessment? Gastrointest Endosc 2010; 71:845-846. 